\title{
Thermoanalytical study on the action of nitric acid in the cassava starch granules
}

\author{
L. S. Ribeiro, L. P. Cordoba, M. M. P. Andrade, C. S. Oliveira, E. C. Silva, \\ T. A. D. Colman, E. Schnitzler \\ State University of Ponta Grossa - Av. Carlos Cavalcanti, 4748. ZIP 84.030-900 - Ponta Grossa-Paraná - Brazil.
}

Received 02/06/2014; accepted 29/07/2014

Available online 26/08/2014

\begin{abstract}
Modifications of starches can led to new products with new desirable properties and applications in several industrial fields as food, textile, paper and others. In this study samples of cassava starch were treated with standard nitric acid 0.1 and 0.2 mol L $^{-1}$ at 25 and $45^{\circ} \mathrm{C}$, respectively, by 60 minutes. After washed, dried and maintained in desiccator up to constant mass, the samples were analysed by TG/DTG whose technique allowed observing three main mass losses and the treated starches shown higher stability in the decomposition. When compared with the untreated cassava starch the gelatinization enthalpy (DSC) of the treated starches decreased mainly with the samples treated with acid at $0.2 \mathrm{~mol} \mathrm{~L}^{-1}$. The increase of acid concentration and temperature show decrease in the relative crystallinity and low alterations in the average diameter of starch granules.
\end{abstract}

Keywords: Cassava starch, acid hydrolysis, thermal behaviour

\section{Introduction}

Starch is a raw material that can be from different botanical sources; is a semi-crystalline polymer and constituted by two polysaccharides: the amylose (mostly linear chain, with up to 3000 glucose molecules interconnected primarily by $\alpha-1,4$ glycosidic linkages and few branched networks) and amylopectin (a large branched polymer with linkages of $\alpha-1,4$ that serve as the backbone and $\alpha-1,6$ bridges at the branching points. In its native form, starch has some technological constraints that need to be improved in order to make it possible and use it in industrial applications. Starches in the native form have some limitations in its applications thus the modified starches are largely used in several industries due to their different functionalities and new desirable properties [1-ㅡ].

The cassava (Manihot esculenta, Crantz) is a species from the Euphorbiaceous family and one of the most important root crops mainly in tropical countries that serve as subsistence food. These roots and tubers are good source of food energy production. It water content is around $70-80 \%$ and are rich in starch (16-24\%) and low quantity of vitamins, minerals, proteins, lipids and other substances $[\underline{1}$, $\underline{3}, \underline{7}-\underline{9}]$.

In agreement with the literature [10] the modified starches with acids (mainly $\mathrm{HCl}, \mathrm{H}_{2} \mathrm{SO}_{4}$ and organic acids) are called "acid modified starches" or termed "acid-thinned starches" that diminishes the molar mass and increasing consequently the free aldehyde group content. The acid hydrolysis also decreases the viscosity of the slurry of starch granules.
In this investigation were made modifications in cassava starch granules with nitric acid in different concentrations and temperatures (this above the gelatinization enthalpy) and the effects upon the starch granules were analysed by thermoanalytical techniques (TG/DTG, DSC), the viscosity profile of starch slurry by RVA, and the structure of granules by atomic force microscopy (AFM) and $\mathrm{X}$ ray diffractometry (XRD).

\section{Experimental}

\subsection{Material and Methods}

The native cassava starch $(500 \mathrm{~g})$ for this study was bought in the local commerce of Ponta Grossa, PR, Brazil. The starch was divided in five parts of $100 \mathrm{~g}$ (dry basis). One of them was maintained as received, being the (A) sample, and the other samples were treated following the literature methodology $[\underline{1}, \underline{8}]$ with modifications: the cassava starches were treated with standard nitric acid solutions by 60 minutes 0.1 and $0.2 \mathrm{~mol} \mathrm{~L}^{-1}$ at 25 and $45^{\circ} \mathrm{C}$, respectively. Then the modified samples were washed and filtered until complete elimination of $\mathrm{NO}_{3}^{-}$ions, dried in room temperature and maintained in desiccator up to constant mass.

The TG curves were obtained with the thermal analysis system TGA-50 (Shimadzu, Japan), where the samples were heated from $35{ }^{\circ} \mathrm{C}$ to $650{ }^{\circ} \mathrm{C}$ using open alumina crucibles with approximately $5.0 \mathrm{mg}$ of each sample under a synthetic air flow of $150 \mathrm{~mL} \mathrm{~min}{ }^{-1}$ at a heating rate of $10{ }^{\circ} \mathrm{C} \mathrm{min}{ }^{-1}$. The instrument was preliminarily calibrated with standard weight and with standard calcium oxalate monohydrate. All mass loss percentages were determined using TA-60 WS data analysis software. The derivative 
thermogravimetric curves (DTG), the first derivative of TG curves, were calculated $[\underline{3}, \underline{4}, \underline{7}, \underline{11}-\underline{17}]$.

The DSC curves were obtained using the thermal analysis system model DSC-Q200 (TA-Instruments, USA) with the aim to investigate the gelatinization enthalpy. The DSC curves were recorded under an air flow of $50 \mathrm{~mL} \mathrm{~min}^{-1}$, heating rate of $10{ }^{\circ} \mathrm{C} \mathrm{min}^{-1}$ and samples weighing about $2.5 \mathrm{mg}$. A 4:1 (water:starch, $\mathrm{m} / \mathrm{m}$ ) mixture was prepared and maintained for 60 minutes in order to equilibrate the moisture content. The aluminum crucibles were sealed and then the curves were performed. The instrument was previously calibrated with Indium $99.99 \%$ purity, melting point with $T_{p} .=156.6^{\circ} \mathrm{C}, \Delta H=28.56 \mathrm{~J} \mathrm{~g}^{-1}[\underline{10}-\underline{13}]$.

The pasting properties of the samples were obtained by using the RVA-4 (Newport Sci., Australia) viscometer. A suspension of $3 \mathrm{~g}$ of starch in $25 \mathrm{~g}$ accurately distilled water underwent a controlled heating and cooling cycle under constant shear where it was held at $50{ }^{\circ} \mathrm{C}$ for two min, heated from 50 to $95^{\circ} \mathrm{C}$ at $6{ }^{\circ} \mathrm{C} \mathrm{min}{ }^{-1}$, and held at $95^{\circ} \mathrm{C}$ for 5 min, cooled to $50^{\circ} \mathrm{C}$ at $6{ }^{\circ} \mathrm{C} \mathrm{min}{ }^{-1}$ and maintained at $50{ }^{\circ} \mathrm{C}$ for $2 \mathrm{~min}$ [12-14].

X-ray diffraction powder patterns (XRD) were obtained by using an X-ray diffractometer mod. Ultima 4 (Rigaku, Japan), employing $\mathrm{Cu} \mathrm{K} \alpha$ radiation $(\lambda=1.541 \AA$ ) and settings of $40 \mathrm{kV}$ and $20 \mathrm{~mA}$. The scattered radiation was detected in the angular range of $5-50^{\circ}(2 \theta)$, with scanning speed of $8^{\circ} \mathrm{min}^{-1}$ and a step of $0.06^{\circ}$. The degree of relative crystallinity was quantitatively estimated using Equation 1 and following the method described in the literature [11, 15-19].

$$
X_{c}=\frac{A_{p}}{\left(A_{p}+A_{b}\right)} \times 100 \quad \text { Equation } 1
$$

The micro-images of each sample with high resolution were observed using an atomic force microscope SPM-9600 (Shimadzu, Japan), by the non-contact method (NC-AFM). All the measurements were performed in triplicate and this technique allowed us to observe the surface of the studied starches and it was possible to calculate the average diameter and the average roughness of the samples $[\underline{10}, \underline{11}, \underline{18}]$.

All the results were studied and analysed its variance (ANOVA) with the Tukey test to compare sample means at 95\% confidence level $(\mathrm{p}<0.05)$ was performed using STATISTICA 7.0 software (StatSoft, Inc., Tulsa, OK, USA) $[\underline{3}, \underline{11}]$.

\section{Results and Discussion}

TG/DTG curves were performed and allowed to verify similar profile of each curve showing three main mass losses with distinct regions; the first, which begins in the room temperature up to around $189{ }^{\circ} \mathrm{C}$, was due to water evaporation. After dehydration each sample shows stability, followed by two steps of decomposition $\left(2^{\text {nd }}\right.$ and $3^{\text {rd }}$ mass losses) attributed to degradation and oxidation of organic matter (amylose and amylopectin), that occurs in oxidant atmosphere with formation of final residue (ash) that were, $0.98,0.66,0.56,0.11$ and $0.55 \%$ of initial mass, respectively. All the TG/DTG curves are depicted in Figure 1 and the obtained results are shown in Table 1.

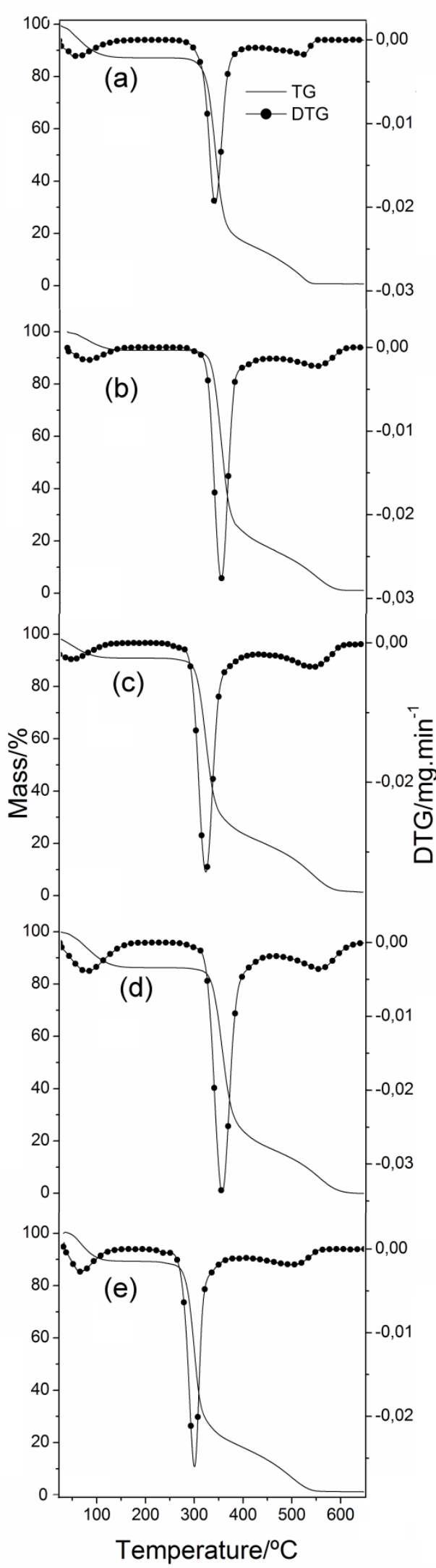

Figure 1: TG/DTG curves of: (a) untreated cassava starch; (b) cassava starch treated with $\mathrm{HNO}_{3} 0,1 \mathrm{~mol} \mathrm{~L}^{-1}$ at $25^{\circ} \mathrm{C}$, (c) cassava starch treated with $\mathrm{HNO}_{3} 0,1 \mathrm{~mol} \mathrm{~L}^{-1}$ at $45^{\circ} \mathrm{C}$; (d) cassava starch treated with $\mathrm{HNO}_{3} 0,2 \mathrm{~mol} \mathrm{~L}^{-1}$ at $25^{\circ} \mathrm{C}$; (e) cassava starch treated with $\mathrm{HNO}_{3} 0,2 \mathrm{~mol} \mathrm{~L}^{-1}$ at $45^{\circ} \mathrm{C}$. 
In low acid concentrations $\left(0.1 \mathrm{~mol} \mathrm{~L}^{-1}\right)$ the treated starches show increase in the final stability (TG) up to 616 and $619{ }^{\circ} \mathrm{C}$, respectively and the starch treated with acid at $0.2 \mathrm{~mol} \mathrm{~L}{ }^{-1}$ at $25^{\circ} \mathrm{C}$ up to $631^{\circ} \mathrm{C}$. To the starch treated with $\mathrm{HNO}_{3} 0.2 \mathrm{~mol} \mathrm{~L}{ }^{-1}$ at $45^{\circ} \mathrm{C}$ this final stability was down up to $610{ }^{\circ} \mathrm{C}$. All the steps of decomposition with the obtained values of TG/DTG are gathered in Table 1.

Table 1: TG/DTG results of: (a) untreated cassava starch; (b) cassava starch treated with $\mathrm{HNO}_{3} 0,1 \mathrm{~mol} \mathrm{~L}{ }^{-1}$ at $25^{\circ} \mathrm{C}$,

(c) cassava starch treated with $\mathrm{HNO}_{3} 0,1 \mathrm{~mol} \mathrm{~L} \mathrm{~L}^{-1}$ at $45^{\circ} \mathrm{C}$;

(d) cassava starch treated with $\mathrm{HNO}_{3} 0,2 \mathrm{~mol} \mathrm{~L} \mathrm{~L}^{-1}$ at $25^{\circ} \mathrm{C}$; (e) cassava starch treated with $\mathrm{HNO}_{3} 0,2 \mathrm{~mol} \mathrm{~L}-1$ at $45^{\circ} \mathrm{C}$.

\begin{tabular}{cllcc}
\hline \multirow{2}{*}{ Samples } & \multicolumn{2}{c}{ TG Results } & \multicolumn{2}{c}{ DTG Results } \\
\cline { 2 - 5 } & \multicolumn{1}{c}{ Step } & \multicolumn{1}{c}{$\Delta \boldsymbol{m} / \%$} & \multicolumn{1}{c}{$\boldsymbol{\prime}^{\mathbf{}} \mathbf{C}$} & $\boldsymbol{T}_{\boldsymbol{p}}{ }^{\circ} \mathbf{C}$ \\
\hline \multirow{4}{*}{ (A) } & $1^{\text {st }}$ & 12.81 & $30-175$ & 50.86 \\
& stability & - & $175-266$ & - \\
& $2^{\text {nd }}$ & 71.52 & $266-416$ & 341.80 \\
& $3^{\text {rd }}$ & 14.69 & $416-594$ & 521.17 \\
\hline & $1^{\text {st }}$ & 6.98 & $30-177$ & 81.82 \\
& stability & - & $177-278$ & - \\
& $2^{\text {nd }}$ & 74.54 & $278-444$ & 353.45 \\
& $3^{\text {rd }}$ & 17.82 & $444-616$ & 550.03 \\
\hline & $1^{\text {st }}$ & 9.21 & $30-189$ & 91.26 \\
& stability & - & $189-289$ & - \\
& $2^{\text {nd }}$ & 70.30 & $289-444$ & 348.43 \\
& $3^{\text {rd }}$ & 19.93 & $444-619$ & 549.77 \\
\hline \multirow{4}{*}{ (D) } & $1^{\text {st }}$ & 13.64 & $30-185$ & 80.75 \\
& stability & - & $185-268$ & - \\
& $2^{\text {nd }}$ & 69.39 & $268-459$ & 356.75 \\
& $3^{\text {rd }}$ & 16.86 & $459-631$ & 548.25 \\
\hline \multirow{3}{*}{ (E) } & $1^{\text {st }}$ & 10.73 & $30-161$ & 65.02 \\
& stability & - & $161-232$ & - \\
& $2^{\text {nd }}$ & 70.58 & $232-387$ & 300.73 \\
& $3^{\text {rd }}$ & 18.14 & $387-610$ & 494.95 \\
\hline
\end{tabular}

$*(\theta)$ Temperature ranges, $\left(T_{p}\right)$ peak temperatures and $(\Delta m)$ mass losses compound. As observed, with major acid concentration and major temperature the $2^{\text {nd }}$ and $3^{\text {rd }}$ decomposition steps were shifted to higher temperatures, except to the sample treated with $\mathrm{HNO}_{3}$ at $0.2 \mathrm{~mol} \mathrm{~L}{ }^{-1}$ and at $45^{\circ} \mathrm{C}$.

The DSC curves were performed with the aim of calculate the gelatinization enthalpy. This is an endothermic phenomenon that occurs when water is added up to starch and heated; it occurs only in sealed crucibles and the energy required for the molecular order disrupter differs in the same botanical origin of starch and the way that it was treated. The characteristic of these transitions including "on set" and "end set" temperature $\left(\mathrm{T}_{\mathrm{on}}, \mathrm{T}_{\mathrm{end}}\right)$, "peak temperature" $\left(\mathrm{T}_{\mathrm{p}}\right)$ and "gelatinization enthalpy" $\left(\Delta \mathrm{H}_{\mathrm{gel}}\right)$ were calculated and are shown in Table 2. The shown DSC curves in Figure 2.

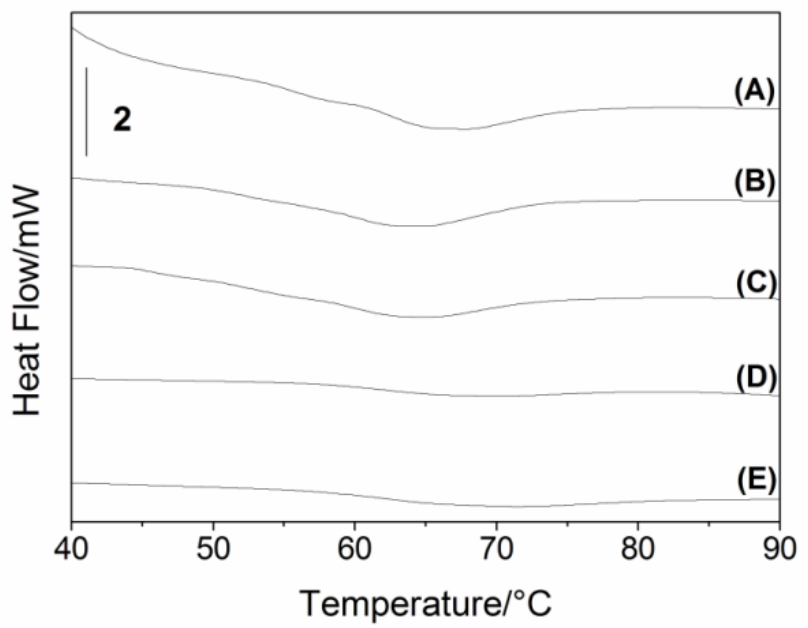

Figure 2: DSC curves of: (a) untreated cassava starch; (b) cassava starch treated with $\mathrm{HNO}_{3} 0,1 \mathrm{~mol} \mathrm{~L}{ }^{-1}$ at $25^{\circ} \mathrm{C}$, (c) cassava starch treated with $\mathrm{HNO}_{3} 0,1 \mathrm{~mol} \mathrm{~L} \mathrm{~L}^{-1}$ at $45^{\circ} \mathrm{C}$; (d) cassava starch treated with $\mathrm{HNO}_{3} 0,2 \mathrm{~mol} \mathrm{~L}^{-1}$ at $25^{\circ} \mathrm{C}$; (e) cassava starch treated with $\mathrm{HNO}_{3} 0,2 \mathrm{~mol} \mathrm{~L}{ }^{-1}$ at $45^{\circ} \mathrm{C}$.

The DTG curves were calculated and the obtained results allowed us to determine the stability of each

Although occurring in approximated temperatures the acid hydrolysis affect the gelatinization properties $(\Delta H)$ that were shifted to lower values, mainly with the increase of temperature and acid concentration. Similar behaviour was observed in previous studies of starches treated with different acids and concentrations $[\underline{1}, \underline{3}, \underline{7}, \underline{8}]$. Other authors $[\underline{12}]$ found similar behaviour in study with corn starches treated with $\mathrm{HCl}$ solutions at $0.06,0.14$ and $1.0 \mathrm{~N}$.

Table 2: DSC, AFM and XRD results of: (a) untreated cassava starch; (b) cassava starch treated with $\mathrm{HNO}_{3} 0,1 \mathrm{~mol} \mathrm{~L}^{-1}$ at $25^{\circ} \mathrm{C}$, (c) cassava starch treated with $\mathrm{HNO}_{3} 0,1 \mathrm{~mol} \mathrm{~L}{ }^{-1}$ at $45^{\circ} \mathrm{C}$; (d) cassava starch treated with $\mathrm{HNO}_{3} 0,2 \mathrm{~mol} \mathrm{~L}^{-1}$ at $25^{\circ} \mathrm{C}$; (e) cassava starch treated with $\mathrm{HNO}_{3} 0,2 \mathrm{~mol} \mathrm{~L}^{-1}$ at $45^{\circ} \mathrm{C}$.

\begin{tabular}{|c|c|c|c|c|c|c|c|}
\hline \multirow[b]{2}{*}{ Samples } & \multicolumn{4}{|c|}{ DSC gelatinization } & \multicolumn{2}{|c|}{ AFM } & \multirow{2}{*}{$\begin{array}{c}\text { XRD } \\
\begin{array}{c}\text { Degree of } \\
\text { relative } \\
\text { cristallinity }\end{array}\end{array}$} \\
\hline & $\mathrm{T}_{o n} /{ }^{\circ} \mathrm{C}$ & $T_{p} /{ }^{\circ} \mathrm{C}$ & $T_{\text {end }} /{ }^{\circ} \mathrm{C}$ & $\Delta H_{\mathrm{gel}} / \mathrm{J} \mathrm{g}^{-1}$ & $d_{a} / \mu \mathrm{m}$ & $r_{a} / n \mathrm{~m}$ & \\
\hline (a) & $58,76 \pm 0,26^{\mathrm{a}}$ & $68,31 \pm 0,07^{\mathrm{b}}$ & $71,28 \pm 0,01^{\mathrm{b}}$ & $13,13 \pm 0,74^{\mathrm{a}}$ & $9.99 \pm 3.49^{\mathrm{b}}$ & 537.200 & $22.39 \pm 2.53^{\mathrm{a}}$ \\
\hline (b) & $52,42 \pm 0,08^{\mathrm{d}}$ & $63,25 \pm 0,09^{\mathrm{d}}$ & $65,61 \pm 0,06^{\mathrm{e}}$ & $10,59 \pm 0,23^{b}$ & $12.52 \pm 4.30^{\mathrm{a}}$ & 729.865 & $19.89 \pm 0.68^{b}$ \\
\hline (c) & $50,61 \pm 0,13^{\mathrm{e}}$ & $63,12 \pm 0,02^{\mathrm{d}}$ & $66,01 \pm 0,04^{\mathrm{d}}$ & $10,51 \pm 0,7^{\mathrm{a}}$ & $9.76 \pm 2.33^{\mathrm{b}}$ & 474.706 & $19.34 \pm 0.16^{\mathrm{ab}}$ \\
\hline (d) & $58,24 \pm 0,08^{\mathrm{b}}$ & $66,79 \pm 0,02^{\mathrm{c}}$ & $70,89 \pm 0,01^{\mathrm{c}}$ & $5,15 \pm 0,32^{c}$ & $9.65 \pm 4.98^{\mathrm{b}}$ & 374.304 & $16.15 \pm 0.75^{b c}$ \\
\hline (e) & $57,25 \pm 0,21^{\mathrm{c}}$ & $69,38 \pm 0,26^{\mathrm{a}}$ & $72,52 \pm 0,15^{\mathrm{a}}$ & $5,04 \pm 0,57^{\mathrm{c}}$ & $8.95 \pm 6.55^{\mathrm{b}}$ & 388.540 & $13.56 \pm 0.29^{c}$ \\
\hline
\end{tabular}

(*) $T_{\text {on }}$ onset temperature, $T_{p}$ peak temperature, $T_{\text {end }}$ endset temperature, $\Delta H_{\text {gel }}$ gelatinization enthalpy, $\left(d_{a}\right)$ Average diameter, $\left(r_{a}\right)$ Average roughness, the degree of crystallinity was calculated as a percentage, peaks are determined in $2 \theta$.

(**)Averages followed by the same letters in the same column do not differ statistically by Tukey's test $(p<0.05)$. 
The atomic force microscopy technique (AFM) turn it possible to observe the starch granules surface with high resolution and some effects of acid treatment at 25 and $45^{\circ} \mathrm{C}$. In Figure 3 we can verify that the granule structure was modified but not destroyed; the average diameter was maintained around 9-12 $\mu \mathrm{m}$ and the average roughness show slight alteration as few bulges in the surface. The results average roughness and the average diameter were calculated and the results are collected in Table 2.

In Figure 4 are shown the main X-ray diffractogram of the studied samples. The diffractograms are characteristic of starch from tuberous with no displacement in the main peaks at $2 \theta$ around $15,17,18$ and $23^{\circ}$. According to the literature $[\underline{8}, \underline{13}]$ with the Equation 1, was calculated the relative crystallinity of untreated and modified starches and the results are depicted in Table 2.

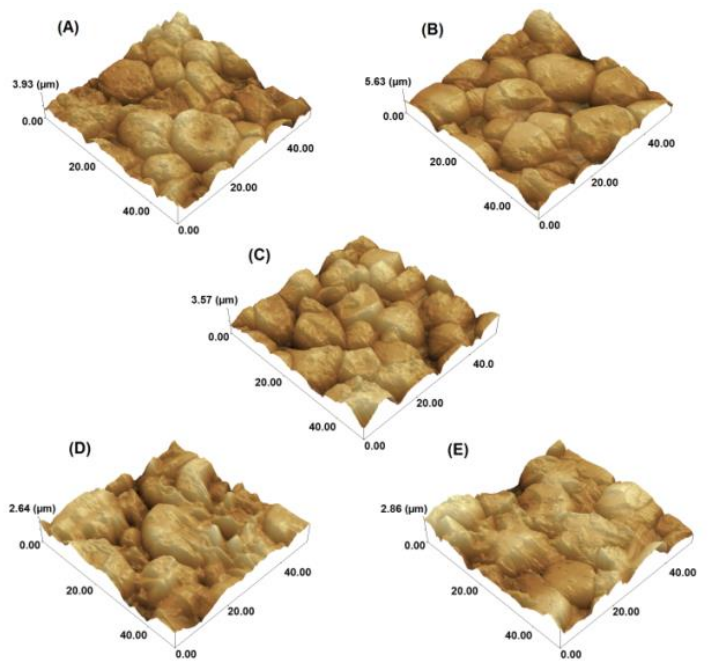

Figure 3: NC-AFM images of: (a) untreated cassava starch; (b) cassava starch treated with $\mathrm{HNO}_{3} 0,1 \mathrm{~mol} \mathrm{\textrm {L } ^ { - 1 }}$ at $25^{\circ} \mathrm{C}$,

(c) cassava starch treated with $\mathrm{HNO}_{3} 0,1 \mathrm{~mol} \mathrm{~L} \mathrm{~L}^{-1}$ at $45^{\circ} \mathrm{C}$;

(d) cassava starch treated with $\mathrm{HNO}_{3} 0,2 \mathrm{~mol} \mathrm{~L}^{-1}$ at $25^{\circ} \mathrm{C}$;

(e) cassava starch treated with $\mathrm{HNO}_{3} 0,2 \mathrm{~mol} \mathrm{~L}^{-1}$ at $45^{\circ} \mathrm{C}$.

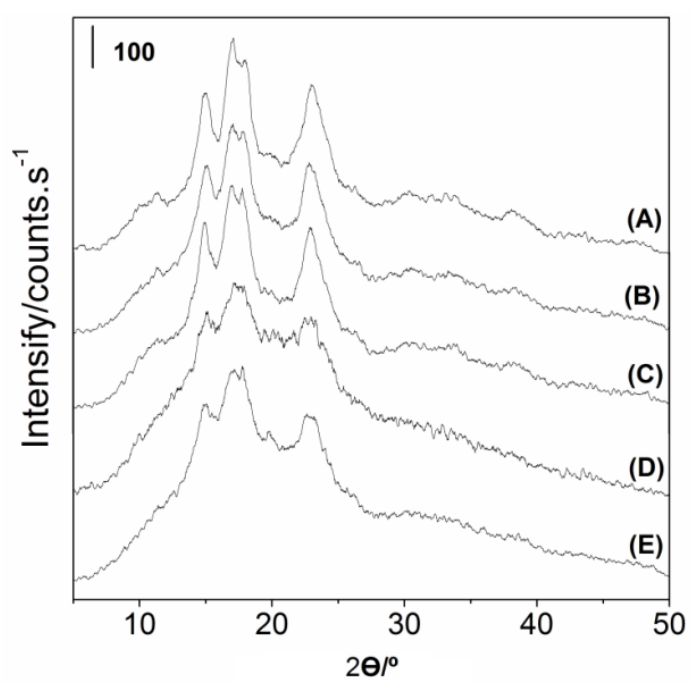

Figure 4: XRD diffractograms of: (a) untreated cassava starch; (b) cassava starch treated with $\mathrm{HNO}_{3} 0,1 \mathrm{~mol} \mathrm{~L}^{-1}$ at $25^{\circ} \mathrm{C}$, (c) cassava starch treated with $\mathrm{HNO}_{3} 0,1 \mathrm{~mol} \mathrm{~L}{ }^{-1}$ at $45^{\circ} \mathrm{C}$; (d) cassava starch treated with $\mathrm{HNO}_{3} 0,2 \mathrm{~mol} \mathrm{~L} \mathrm{~L}^{-1}$ at $25^{\circ} \mathrm{C}$; (e) cassava starch treated with $\mathrm{HNO}_{3} 0,2 \mathrm{~mol} \mathrm{~L}^{-1}$ at $45^{\circ} \mathrm{C}$.
The obtained results shown that some difference in relative crystallinity occurs in the starch granules mainly with those treated with acid at $45^{\circ} \mathrm{C}$. The obtained values of relative crystallinity are collected in Table 2.

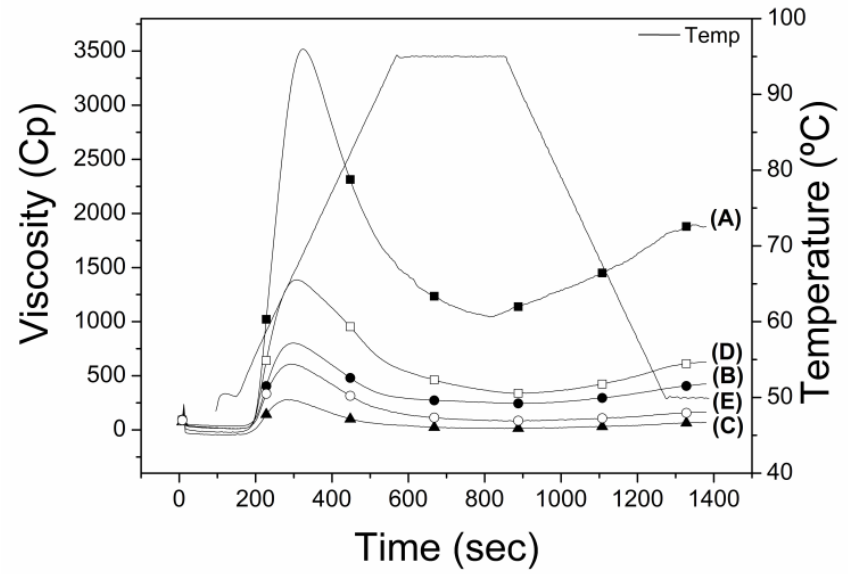

Figure 5: RVA viscograms of: (a) untreated cassava starch; (b) cassava starch treated with $\mathrm{HNO}_{3} 0,1 \mathrm{~mol} \mathrm{~L}^{-1}$ at $25^{\circ} \mathrm{C}$, (c) cassava starch treated with $\mathrm{HNO}_{3} 0,1 \mathrm{~mol} \mathrm{~L}^{-1}$ at $45^{\circ} \mathrm{C}$; (d) cassava starch treated with $\mathrm{HNO}_{3} 0,2 \mathrm{~mol} \mathrm{~L}{ }^{-1}$ at $25^{\circ} \mathrm{C}$; (e) cassava starch treated with $\mathrm{HNO}_{3} 0,2 \mathrm{~mol} \mathrm{~L}{ }^{-1}$ at $45^{\circ} \mathrm{C}$.

The viscograms (RVA) of untreated (a) and modified starches (b-e) are shown in Figure 5 and the results depicted in Table 3. As reported in literature [고요 $\underline{8}, \underline{3}]$, after the acid treatment of native starch the pasting properties can be shifted to higher temperatures and the acid action causes decrease in the viscosity of slurry with increase of temperature.

After reaching the maximum viscosity (at $95{ }^{\circ} \mathrm{C}$ ) all the samples lose this property that returns with lower intensity after cooling (final viscosity). 
Table 3: RVA results of: (a) untreated cassava starch; (b) cassava starch treated with $\mathrm{HNO}_{3} 0,1 \mathrm{~mol} \mathrm{~L}^{-1}$ at $25^{\circ} \mathrm{C}$, (c) cassava starch treated with $\mathrm{HNO}_{3} 0,1 \mathrm{~mol} \mathrm{~L}{ }^{-1}$ at $45^{\circ} \mathrm{C}$; (d) cassava starch treated with $\mathrm{HNO}_{3} 0,2 \mathrm{~mol} \mathrm{~L}^{-1}$ at $25^{\circ} \mathrm{C}$; (e) cassava starch treated with $\mathrm{HNO}_{3} 0,2 \mathrm{~mol} \mathrm{~L}^{-1}$ at $45^{\circ} \mathrm{C}$.

\begin{tabular}{ccccccc}
\hline Samples & $\begin{array}{c}\text { Pasting } \\
\text { temperature/ }{ }^{\circ} \mathbf{C}\end{array}$ & $\begin{array}{c}\text { Viscosity } \\
\text { peak/cP }\end{array}$ & Peak time/sec & Setback/cP & Break/cP & $\begin{array}{c}\text { Final } \\
\text { viscosity/cP }\end{array}$ \\
\hline (a) & $63,45 \pm 1,13^{\mathrm{a}}$ & $3516,00 \pm 2,83^{\mathrm{a}}$ & $326,00 \pm 2,83^{\mathrm{a}}$ & $827,00 \pm 8,49^{\mathrm{a}}$ & $2442,00 \pm 14,14^{\mathrm{a}}$ & $1874,5 \pm 3,54^{\mathrm{a}}$ \\
(b) & $64,48 \pm 1,38^{\mathrm{a}}$ & $800,00 \pm 2,83^{\mathrm{c}}$ & $301,90 \pm 8,63^{\mathrm{b}}$ & $178,50 \pm 0,71^{\mathrm{c}}$ & $556,00 \pm 2,83^{\mathrm{c}}$ & $422,50 \pm 0,71^{\mathrm{c}}$ \\
(c) & $66,68 \pm 3,36^{\mathrm{a}}$ & $277,00 \pm 2,69^{\mathrm{e}}$ & $281,90 \pm 2,69^{\mathrm{c}}$ & $52,00 \pm 2,83^{\mathrm{e}}$ & $262,5 \pm 3,54^{\mathrm{d}}$ & $66,50 \pm 0,71^{\mathrm{e}}$ \\
(d) & $63,50 \pm 1,06^{\mathrm{a}}$ & $1384,50 \pm 3,54^{\mathrm{b}}$ & $307,90 \pm 0,14^{\mathrm{ab}}$ & $288,00 \pm 2,83^{\mathrm{b}}$ & $1046,50 \pm 6,36^{\mathrm{b}}$ & $625,98 \pm 0,04^{\mathrm{b}}$ \\
(e) & $64,75 \pm 1,77^{\mathrm{a}}$ & $608,00 \pm 1,41^{\mathrm{d}}$ & $296,10 \pm 5,52^{\mathrm{bc}}$ & $81,50 \pm 4,95^{\mathrm{d}}$ & $528,00 \pm 1,41^{\mathrm{c}}$ & $163,50 \pm 2,12^{\mathrm{d}}$ \\
\hline
\end{tabular}

(*) cP "centipoises", sec "seconds".

(**) Averages followed by the same letters in the same column do not differ statistically by Tukey's test $(p<0.05)$.

\section{Conclusions}

The TG curves show characteristic steps of decomposition for untreated and modifies starches. DSC analysis was an important tool to determine the main gelatinization properties of starches. A reduction in $\Delta \mathrm{H}_{\text {gel }}$ of the starches treated with nitric acid occurs in agreement with the treatment with other inorganic acids $\left(\mathrm{HCl}, \mathrm{H}_{2} \mathrm{SO}_{4}\right)$ that primarily attacks the amorphous regions and plays an important role in the thermodynamics and physicochemical properties without destroying its granule structure as it can be observed by atomic force microscopy. The relative crystallinity of starch granules decreased mainly in higher acid concentrations and temperatures.

\section{Acknowledgements}

The authors would like to thank CAPES, CNPq and the Araucaria Foundation, Brazil for their financial support.

\section{References}

[1] Beninca C, Demiate IM, Lacerda LG, Carvalho-Filho MAS, Ionashiro M, Schnitzler E. Thermal behavior of corn starch granules modified by acid treatment at 30 and $50{ }^{\circ} \mathrm{C}$. Ecl. Quím. 2008:33(3):13-18. [Google Scholar [Available from] [CrossRef]

[2] Franco CML, Cabral RAF, Tavares DQ Structural and physicochemical characteristics of lintnerized native and sour cassava starches. Starch/Stärke. 2002:54(10):469-475.

[Google Scholar] [Available from] [CrossRef]

[3] Oliveira CS, Andrade MMP., Colman TAD, Costa FJOG, Schnitzler E. Thermal, structural and rheological behavior of native and modified waxy corn starch with hydrochloric acid at different temperatures. J. Therm. Anal. Calorim. 2014:115(1):13-18. [Google Scholar] [Available from] [CrossRef]

[4] Kaur B, Ariffin F, Bhat R, Karim A. Progress in starch modification in the last decade. Food Hydrocoll. 2012:26(2):398-404. [Google Scholar] [Available from] [CrossRef]
[5] Xiao H, Lin Q, Liu G, Yu F. A Comparative Study of the Characteristics of Cross-Linked, Oxidized and Dual-Modified Rice Starches. Molecules. 2012:17(9):10946-10957. [Google Scholar] [Available from] [PubMed] [CrossRef]

[6] Garrido LH, Schnitzler E, Zortea MEB, Rocha TS, Demiate IM. Physicochemical properties of cassava starch oxidized by sodium hypochlorite. J. Food Sci. Technol. 2012:10:794-799. [Google Scholar] [Available from] [CrossRef]

[7] Beninca C, Colman TAD, Lacerda LG, Filho MASC, Bannach G, Schnitzler E. The thermal, rheological and structural properties of cassava starch granules modified with hydrochloric acid at different temperatures. Thermochim. Acta. 2013:552:65-69. [Google Scholar] [Available from] [CrossRef]

[8] Cordoba LP, Ribeiro LS, Colman TAD, Oliveira CS, Andrade MMP, Costa FJOG, Schnitzler E. Effect of hydrochloric acid in different concentrations and temperatures up to some properties of organic cassava starch. Braz. J. Therm. Anal. 2013:2(1):6-11. [Google Scholar] [Available from]

[9] Lacerda LG, Azevedo JAM, Filho MASC, Demiate IM, Schnitzler E, Vandenberghe LPS, Soccol CR. Thermal characterization of partially hydrolyzed cassava (Manihoc esculenta) starch granules. Braz. Arch. Biol. Technol. 2008:51(6):1209-1216. [Google Scholar] [Available from] [CrossRef]

[10] Leivas CL, Costa FJOG, Almeida RR, Freitas RJS, Stertz SC, Schnitzler E. Structural characteristics, physico-chemical, thermal and pasting properties of potato (Solanum tuberosum L.) flour: study of different cultivars and granulometries. J. Therm. Anal. Calorim. 2014:111(3):2211-2216. [Google Scholar] [Available from] [CrossRef]

[11] Colman TAD, Demiate IM, Schnitzler E. The effect of microwave radiation on some thermal, rheological and structural properties of cassava starch. J. Therm. Anal. Calorim. 
2014:115(3):2245-2252. [Google Scholar] [Available from] [CrossRef]

[12] Shandu KS, Singh N, Lim S-T. A comparison of native and thinned normal and waxy corn starches: physicochemical, thermal, morphological and pasting properties. LWT-Food Sci. Technol. 2007:40(9):1527-1536. [Google Scholar] [Available from] [CrossRef]

[13] Wang Y-J, Truong V-D, Wang L. Structures and rheological properties of corn starch as affected by acid hydrolysis. Carbohydr. Polym. 2003:52(3):327-333. [Google Scholar] AAvailable from] [CrossRef]

[14]Zhang L, Xie W, Zhao X, Liu Y, Gao W. Study on the morphology, crystalline structure and thermal properties of yellow ginger starch acetates with different degrees of substituition. Thermochim. Acta. 2009:495(1-2):57-62. [Google Scholar] [Available from] [CrossRef]

[15] Atichokudomchai N, Varavinit S. Characterization and utilization of acid-modified cross-linked Tapioca starch in pharmaceutical tablets. Carbohydr. Polym. 2003:53(3):263-270. [Google Scholar] [Available from] [CrossRef]

[16] Hoover R. Acid treated starches. Food Rev. Int. 2000:16(3):369-392. [Google Scholar] [Available from] [CrossRef]

[17] Plata-Olviedo M, Camargo C. Effect of acid treatments and drying processes on physicochemical and functional properties of cassava starch. J. Sci. Food Agric. 1998:77(1):103-108. [Google Scholar] [Available from] [CrossRef]

[18] Sun Q, Zhu X, Si F, Xiong L. Effect of acid hydrolysis combined with heat moisture treatment on structure and physicochemical properties of corn starch. J. Food Sci. Technol. 2013. [Google Scholar] [Available from] [CrossRef]

[19] Chung H-J, Jeong H-Y, Lim S-T. Effects of acid hydrolysis and defatting on crystallinity and pasting properties of freeze-thawed high amylose corn starch. Carbohydr. Polym. 2003:54:449-455. [Google Scholar] [Available from] [CrossRef] 